\title{
The effect of smoking on the response to raloxifene treatment in postmenopausal osteoporosis
}

\author{
Sigara içiminin postmenopozal osteoporozda raloksifen tedavi yanıtına etkisi
}

\author{
Savaş Erdem, Ayşe Filiz Yavuz Avşar, Hüseyin Levent Keskin, Gülin Feykan Yeğin Akçay, Elçin İşlek Seçen
}

\begin{abstract}
Objectives: The aim of this study was to examine the effect of smoking on the efficacy of raloxifene treatment in postmenopausal osteoporosis.

Materials and methods: In this cross-sectional study, raloxifene $\mathrm{HCl}(60 \mathrm{mg} /$ day) and $600 \mathrm{mg}$ ionized calcium + 400 IU vitamin D/day treatment were given to 63 cases (nonsmoker group $n=39$, smoker group $n=24$ ), who were in the postmenopausal period and detected as having osteoporosis. At the end of the first year of the treatment, the bone mineral densities (BMDs; $\mathrm{g} / \mathrm{cm}^{2}$ ) were measured at four regions, namely the femur neck, femur trochanter, total hip, and lumbar vertebrae between L1-4, and T-scores were determined. The changes in BMDs were compared between the two groups.
\end{abstract}

Results: Before starting the treatment, the mean ages (55.8 \pm 3.3 vs. $53.0 \pm 1.3$ years), menopausal ages (49.3 \pm 2.9 vs. $48.1 \pm 2.1$ years), postmenopausal periods (5.0 \pm 1.3 vs. $7.0 \pm 1.4$ years), body mass indexes, and estradiol levels were found to be significantly not different between the two groups ( $p>0.05$ ). At the beginning of treatment, the BMD values were not different for all measured regions in both groups $(p>0.05)$. At the end of the first year of the treatment, statistically significant improvements in BMD values and T-scores were detected for all measured regions in the nonsmoker group $(p<0.05)$. However, there were no significant differences in the BMD values from the initial values in the smoker group after treatment $(p>0.05)$.

Conclusions: The treatment efficacy of raloxifene in improving BMD values in postmenopausal osteoporosis is negatively influenced by smoking. J Clin Exp Invest 2012; 3(4): 457-462

Key words: Raloxifene, postmenopausal osteoporosis, smoking

\section{ÖZET}

Amaç: Bu çalışmada amacımız, postmenopozal osteoporoz tedavisinde raloksifen kullanan kadın-larda, sigara içiminin tedavinin etkinliğine olan etkisini incelemektir.

Gereç ve yöntem: Bu kesitsel çalışmada, postmenopozal döneminde olan ve osteoporoz saptanan 88 (sigara içmeyen $n=54$, sigara içen $n=34$ ) olguya Raloksifen $\mathrm{HCl}$ (60 mg/gün) + $600 \mathrm{mg}$ iyonize kalsiyum/gün + $400 \mathrm{IU}$ vit D/gün tadavisi verildi. Tedavinin 1.yılı sonunda 63 olguda (Sigara içmeyen grup $n=39$, Sigara içen grup $n=24$ ) DEXA yöntemi kullanılarak L1-4 arası lomber vertebra, femur trokanter, femur boynu ve total kalça (hip) bölgelerinde kemik mineral yoğunlukları $\left(\mathrm{gr} / \mathrm{cm}^{2}\right)$ ölçüldü ve T skorları hesaplandı. İki grup arasında tedavi sonuçları karşılaştırıldı.

Sonuçlar: Raloksifen tedavisine başlanmadan önce her iki grubun ortalama yaş (55,8 $\pm 3,3$ 'e karşı 53,0 $\pm 1,3$ yıl), menopoz yaşları (49,3 $\pm 2,9$ 'a karşı 48,1 $\pm 2,1$ yıl) menopoz süresi $(5,0 \pm 1,3$ 'e karşı 7,0 $\pm 1,4$ yıl), vücut kütle indeksleri $(27,2 \pm 3,7$ 'e karşı $23,4 \pm 0,2 \mathrm{~kg} / \mathrm{m} 2)$ ve estradiol düzeyleri $(26,0 \pm 3,7$ 'e karşı vs $23,4 \pm 0,2)$ arasında anlamIı farklılık saptanmadı $(p>0,05)$. Tedavinin başlangıcında BMD değerleri tüm ölçüm bölgelerinde iki grup arasında farklı değildi $(p>0,05)$.

Raloksifenin BMD üzerine etkisi sigara içen ve içmeyen gruplara göre karşılaştırıldığında sigara içmeyen grupta tüm ölçüm bölgelerinde BMD değerlerinde belirgin düzelme saptanırken $(p<0,05)$, sigara içen grupta ise tüm ölçüm bölgelerinde başlangıç değerlerine göre anlamlı bir düzelme olmadığı görüldü ( $p>0,05)$.

Sonuç: Sigara içmek raloksifenin BMD üzerine olan tedavi etkinliğini olumsuz yönde etkilemektedir.

Anahtar kelimeler: Raloksifen, postmenopozal osteoporoz, sigara 


\section{INTRODUCTION}

Osteoporosis and related bone fractures are a serious community health care problem in the geriatric population. The most important risk factor for osteoporosis is estrogen deficiency, such as that which occurs during menopause. ${ }^{1}$ A variety of pharmacological options are available for the prevention and treatment of osteoporosis including raloxifene. ${ }^{2}$ Raloxifene is a nonsteroidal selective estrogen-receptor modulator (SERM) with estrogen antagonist activity on endometrial tissues and agonist effects on the skeleton and lipid metabolism. ${ }^{3}$ Raloxifene can be recommended for the prevention of vertebral fractures in women with osteopenia/osteoporosis who are not at high risk of nonvertebral fractures and who do not have a past history of venous thromboembolism. ${ }^{4}$

The SERMs bind to both alpha (activator) and beta (inhibitor) estrogen receptors of coregulator protein in target tissues. SERMs function as a partial agonist when binding to the alpha receptors and as a pure antagonist when binding to beta receptor. ${ }^{5}$ In postmenopausal women with osteoporosis, raloxifene competes with endogenous estrogens for binding to estrogen receptors, and it increases BMD and reduces bone turnover and the risk of vertebral fracture. ${ }^{6}$ Raloxifene was shown to decrease the incidence of vertebral fractures by $30-50 \%,{ }^{7}$ but there was no evidence that raloxifene reduced the risk of hip or other nonvertebral fractures. ${ }^{6-8}$

Although a couple of studies did not observe a relationship between smoking and osteoporosis, ${ }^{9-10}$ the incidence of osteoporotic fractures was increased among postmenopausal smokers in other studies. ${ }^{11-12}$ Like raloxifene, components of tobacco bind to estrogen receptors and compete with estradiol. Smoking has been associated with negative effects, including early menopause, ${ }^{13}$ lower body weight, ${ }^{14-15}$ decreased intestinal calcium absorption, ${ }^{16-17}$ increased cortisol synthesis, ${ }^{18}$ and direct toxic effects on bone cells due to increased oxygen-derived free radicals. ${ }^{19}$ Also, in human choriocarcinoma cell cultures, nicotine and other minor components of tobacco were shown to inhibit androstenedione conversion to estrogen by reducing aromatization and inactivation through 2-hydroxylation of estradiol. ${ }^{20}$

As smoking can directly affect estrogen receptors, it can influence the binding of raloxifene to estrogen receptors. Therefore, the therapeutic efficacy of raloxifene can be influenced by smoking. In this study, our aim is to examine the effect of smoking on the efficacy of raloxifene treatment for postmenopausal osteoporosis in women.

\section{MATERIALS AND METHODS}

This cross-sectional study was approved by the Local Ethics Committee. The study examined 141 cases who were admitted for routine postmenopausal checkups and who were postmenopausal for at least 2 years. The menopausal conditions of all the cases were confirmed by amenorrhea and measurements of the follicule-stimulating hormone ( $\mathrm{FSH} ;>35 \mathrm{mlU} / \mathrm{ml})$ and estradiol $(\mathrm{E} 2 ;<37 \mathrm{pg} / \mathrm{ml})$ levels. The natural and surgical menopausal conditions of the cases were not taken into account. The BMDs $(\mathrm{g} / \mathrm{cm} 2)$ were measured with dual energy X-ray absorptiometry (DEXA), and T-scores were calculated. BMD measurements were recorded for the femur neck, trochanter, total hip, and lumbar vertebrae between L1-4. The cases with T-scores $\leq$ -2.5 on at least one region were confirmed as having osteoporosis.

Cases were excluded from the study for the following criteria: use of regular calcium and vitamin $\mathrm{D}$ preparations, previously took or were currently taking hormone replacement therapy or antiosteoporotic therapy, had a disease that may lead to endocrinological or secondary osteoporosis (e.g., cases with thyroid or parathyroid disorders, or insulin-dependent diabetes mellitus, who were using heparin or low molecular weight heparin), had urolithiasis, renal, or liver disorders, had gynecological, breast, or another history of malignancy, had detected endometrial pathology or postmenopausal bleeding, or had severe vasomotor symptom.

The ages, menopausal ages, and postmenopausal durations of the cases were recorded, and the body mass indexes were calculated. Pelvic ultrasonographies, mammographies, endometrial thickness measurements were recorded for all cases. Cervical Pap smear examinations were carried out for all cases with a uterus. Cases were excluded from the study if their endometrial thicknesses were above $5 \mathrm{~mm}$, if they were graded as BIRADS (Breast Imaging Reporting and Data System ) 3 or above by criteria in mammography, or if they had an abnormal cytological finding in the Pap smear examination.

The cases were asked about their smoking habits and were divided into two groups on the basis of smoking. The first group (smokers) actively smoked at least 5 cigarettes/day, and the second group (nonsmokers) never smoked cigarettes. Sub- 
jects who formerly smoked but had not smoked for at least 2 years were considered nonsmokers and were included in the nonsmoker group. The subjects who actively smoked less than 5 cigarettes/ day were excluded from this study.

After applying the inclusion and exclusion criteria listed above, there were 99 cases (nonsmoker group $n=61$, smoker group $n=38$ ), who were included in the study to take raloxifene $\mathrm{HCl}(60 \mathrm{mg} /$ day), $600 \mathrm{mg}$ ionized calcium, and $400 \mathrm{IU}$ vitamin D/ day for osteoporosis treatment. However, 11 of the cases refused to use the drug and were excluded from the study.

Therefore, 88 cases (nonsmokers group $\mathrm{n}=$ 54 , smokers group $n=34$ ) began the antiresorptive treatment. The participants were called for follow ups during the 3rd and 12th months of the treatment. At the follow ups, we assessed their adaptation to drug use, complaints related to the treatment, and the side effects experienced. Ultrasonography was used to repeat the endometrial thickness measurements. Cases were excluded from the study during the treatment period if the subject did not have adaptation to drug use, had an endometrial thickness $>5 \mathrm{~mm}$, had abnormal uterine bleeding, had severe vasomotor symptoms, or were lost to follow up.

By the end of the $1^{\text {st }}$ year of the treatment, the results were evaluated by remeasuring the BMDs of the 24 cases in the smokers group and of the 39 cases in the nonsmokers group. These measurements were then compared between the two groups.

\section{Statistical analysis}

The statistical analyses were carried out by using SPSS version 11.5. Before beginning the statistical analyses, the distribution of the data were tested using the Shapiro-Wilk normality test. The statisti- cal comparisons of the data were carried out by using the paired sample t-test for continuous variables and the Wilcoxon test for categorical variables. A $\mathrm{p}$-value $<0.05$ was accepted as statistically significant.

\section{RESULTS}

Prior to raloxifene treatment, the mean age (55.8 \pm 3.3 years vs. $53.0 \pm 1.3$ years, $p=0.111)$, menopausal age $(49.3 \pm 2.9$ vs $48.1 \pm 2.1$ years, $p=$ $0.343)$, menopausal duration ( $5.0 \pm 1.3$ vs. $7.0 \pm 1.4$ years, $p=0.095)$, BMD values $(27.2 \pm 3.7$ vs 23.4 $\pm 0.2 \mathrm{~kg} / \mathrm{m} 2, p=0.431)$ and estradiol levels $(26.0 \pm$ 3.7 vs. $23.4 \pm 0.2 \mathrm{pg} / \mathrm{ml}, \mathrm{p}=0.380$ ) of both groups were similar. Prior to treatment, the BMD values were similar for all of the measurement regions (L14 lumbar vertebra, trochanter, femur neck, and total hip) in both groups $(p>0.05)$ (Table 1).

At the end of the $1^{\text {st }}$ year of treatment, the pretreatment and post-treatment BMD values in all cases $(n=63)$ were compared. When all of the cases are taken into consideration, there was no significant difference observed in the BMDs of the femur neck region between the pre-treatment and posttreatment groups $(p=0.204)$. In contrast, there was a marked recovery in the BMD values and T-scores for the L1-4 lumbar vertebras, femur trochanter, and total hip after treatment $(p<0.05)$ (Table 2).

Next, the effect of raloxifene on BMD was evaluated between the smoker and nonsmoker groups. There was a marked improvement in the BMD values for all of the measurement regions in the nonsmoker group $(p<0.05)$ (Table 3$)$. In contrast, there was no significant difference between the pre-treatment and post-treatment values for any of the measurement regions in the smoker group $(p$ $>0.05$ ) (Table 4).

Table 1. Baseline bone mineral density of the groups before treatment (Mean \pm SD)

\begin{tabular}{|c|c|c|c|c|c|c|}
\hline & \multicolumn{2}{|c|}{ Smokers $(n=34)$} & \multicolumn{2}{|c|}{ Nonsmokers $(n=54)$} & \multicolumn{2}{|c|}{$P$ values } \\
\hline & $\mathrm{g} / \mathrm{cm}^{2}$ & T-score & $\mathrm{g} / \mathrm{cm}^{2}$ & T-score & $\mathrm{g} / \mathrm{cm}^{2}$ & T-score \\
\hline Spine (L1-4) & $730 \pm 46$ & $-2.88 \pm 0.18$ & $713 \pm 54$ & $-2.95 \pm 0.24$ & 0.353 & 0.460 \\
\hline Trochanter & $405 \pm 43$ & $-2.93 \pm 0.44$ & $411 \pm 46$ & $-2.89 \pm 0.45$ & 0.835 & 0.988 \\
\hline Femur neck & $537 \pm 53$ & $-2.84 \pm 0.49$ & $530 \pm 57$ & $-2.89 \pm 0.51$ & 0.273 & 0.369 \\
\hline Total hip & $580 \pm 53$ & $-2.84 \pm 0.26$ & $573 \pm 50$ & $-2.87 \pm 0.25$ & 0.999 & 0.988 \\
\hline
\end{tabular}


Table 2. Comparison of bone mineral density before and after treatment among all patients $(n=63)(M e a n \pm S D)$

\begin{tabular}{|c|c|c|c|c|c|c|}
\hline & \multicolumn{2}{|c|}{ Before treatment } & \multicolumn{2}{|c|}{ After treatment } & \multicolumn{2}{|c|}{$P$ values } \\
\hline & $\mathrm{g} / \mathrm{cm}^{2}$ & T-score & $\mathrm{g} / \mathrm{cm}^{2}$ & T-score & $\mathrm{g} / \mathrm{cm}^{2}$ & T-score \\
\hline Spine (L1-4) & $731 \pm 41$ & $-2.88 \pm 0.16$ & $749 \pm 40$ & $-2.80 \pm 0.15$ & 0.021 & 0.030 \\
\hline Trochanter & $410 \pm 42$ & $-2.91 \pm 0.30$ & $417 \pm 27$ & $-2.85 \pm 0.18$ & 0.017 & 0.028 \\
\hline Femur neck & $535 \pm 29$ & $-2.85 \pm 0.15$ & $541 \pm 40$ & $-2.82 \pm 0.20$ & 0.351 & 0.204 \\
\hline Total hip & $574 \pm 27$ & $-2.87 \pm 0.13$ & $602 \pm 28$ & $-2.73 \pm 0.13$ & 0.007 & 0.009 \\
\hline
\end{tabular}

Table 3. Comparison of bone mineral density before and after treatment among nonsmokers $(n=39)($ Mean \pm SD)

\begin{tabular}{|c|c|c|c|c|c|c|}
\hline & \multicolumn{2}{|c|}{ Before treatment } & \multicolumn{2}{|c|}{ After treatment } & \multicolumn{2}{|c|}{$P$ values } \\
\hline & $\mathrm{g} / \mathrm{cm}^{2}$ & T-score & $\mathrm{g} / \mathrm{cm}^{2}$ & T-score & $\mathrm{g} / \mathrm{cm}^{2}$ & T-score \\
\hline Spine (L1-4) & $713 \pm 54$ & $-2.95 \pm 0.24$ & $766 \pm 37$ & $-2.73 \pm 0.13$ & 0.001 & 0.011 \\
\hline Trochanter & $411 \pm 46$ & $-2.89 \pm 0.45$ & $429 \pm 57$ & $-2.78 \pm 0.37$ & 0.016 & 0.037 \\
\hline Femur neck & $530 \pm 57$ & $-2.89 \pm 0.51$ & $558 \pm 91$ & $-2.73 \pm 0.44$ & 0.030 & 0.017 \\
\hline Total hip & $573 \pm 50$ & $-2.87 \pm 0.25$ & $608 \pm 40$ & $-2.71 \pm 0.18$ & 0.044 & 0.026 \\
\hline
\end{tabular}

Table 4. Comparison of bone mineral density before and after treatment among smokers $(n=24)($ Mean \pm SD)

\begin{tabular}{|c|c|c|c|c|c|c|}
\hline & \multicolumn{2}{|c|}{ Before treatment } & \multicolumn{2}{|c|}{ After treatment } & \multicolumn{2}{|c|}{$P$ values } \\
\hline & $\mathrm{g} / \mathrm{cm}^{2}$ & T-score & $\mathrm{g} / \mathrm{cm}^{2}$ & T-score & $\mathrm{g} / \mathrm{cm}^{2}$ & T-score \\
\hline Spine (L1-4) & $730 \pm 46$ & $-2.88 \pm 0.18$ & $747 \pm 26$ & $-2.81 \pm 0.10$ & 0.281 & 0.243 \\
\hline Trochanter & $405 \pm 43$ & $-2.93 \pm 0.44$ & $413 \pm 68$ & $-2.87 \pm 0.47$ & 0.473 & 0.544 \\
\hline Femur neck & $537 \pm 53$ & $-2.84 \pm 0.49$ & $543 \pm 86$ & $-2.81 \pm 0.41$ & 0.217 & 0.315 \\
\hline Total hip & $580 \pm 53$ & $-2.84 \pm 0.26$ & $574 \pm 33$ & $-2.88 \pm 0.15$ & 0.801 & 0.760 \\
\hline
\end{tabular}

\section{DISCUSSION}

We found that raloxifene does not influence BMD values significantly in smokers after 1 year of treatment. In contrast, there was a significant improvement in the BMD values in nonsmokers after use of raloxifene for 1 year. Smoking negatively affects the therapeutic antiresorptive effect of raloxifene on BMD.

In a study conducted by a group of Multiple Outcomes of Raloxifene Evaluation (MORE) investigators, it was shown that administration of raloxifene (60 and $120 \mathrm{mg} / \mathrm{d}$ ) for 4 years decreased the cumulative risk of new vertebral fractures in postmenopausal women with osteoporosis. The decreased vertebral fracture risk in year 4 alone was not different between in the first 3 years and 4 th year. $^{8}$

In a randomized, double-blind, placebo- and active-controlled study, healthy postmenopausal women with osteoporosis (55-85 y of age) were treated with bazedoxifene (20 or $40 \mathrm{mg} / \mathrm{d}$ ), raloxi- fene $(60 \mathrm{mg} / \mathrm{d})$, or given a placebo. The authors concluded that SERMs significantly reduced the risk of new vertebral fractures in postmenopausal women with osteoporosis and decreased the risk of nonvertebral fractures in subjects with a higher fracture risk. ${ }^{21}$

Thinness and smoking were described as risk factors for osteoporosis development in a randomized study of 153 early postmenopausal women, but this risk was counteracted by hormone replacement therapy. However, there was no difference with regard to resorption markers and hormone status, and the formation markers decreased approximately $10 \%$ in smokers. The BMD at baseline was $4 \%$ lower in smokers than in nonsmokers. The smokers and nonsmokers responded similarly to the placebo and $2 \mathrm{mg}$ estradiol, but the nonsmokers treated with $1 \mathrm{mg}$ estradiol had a significantly larger response than smokers. ${ }^{22}$

The effect of the frequency of smoking was also examined. The mean total BMD was $4 \%$ lower and 
the total hip density was $6 \%$ lower in heavy smokers (>1 pack/day) compared with nonsmokers. The adjusted mean calcium absorption corrected for weight was lower $(13 \%)$ both in light $(<1$ pack/day) and heavy smokers, but 25-hydroxyvitamin D was significantly lower $(16 \%)$ in heavy smokers. ${ }^{23}$

A previous wide-scale MORE study compared changes in BMD and biochemical markers of bone turnover and the incidence of new vertebral fractures in postmenopausal wome. ${ }^{24}$ In this study, 7705 postmenopausal women with osteoporosis were randomized into groups and given a placebo or raloxifene (60 or $120 \mathrm{mg} / \mathrm{dl}$ ). They concluded that smoking does not influence the antiosteoporotic effect of raloxifene. Of the participants, $17 \%$ were smokers. The smokers had lower osteocalcin, serum 25-hydroxyvitamin $\mathrm{D}$, and parathormone values, and higher urinary type 1 collagen breakdown products. The trochanteric and whole body BMD values were lower in the smoker group than in the nonsmoker group. The percent increases in femoral neck, trochanter, lumbar spine, and whole body BMDs due to raloxifene treatment were not significantly different between smokers and nonsmokers. ${ }^{24}$ The conclusion of that study did not support our results.

The small number of participants in our study is a limitation of this report. When all of the subjects were taken into consideration, at the end of the first year of raloxifene therapy, there was no significant difference in the femur neck BMD values; however, there was a significant improvement in the other regions after treatment. When the BMD values of the smokers and nonsmokers were compared, the pre-treatment and post-treatment values were not significantly different in the smokers group, but in nonsmokers group there was a significant improvement in the femur neck BMD value. In conclusion, smoking negatively affects the therapeutic antiresorptive effect of raloxifene on BMD.

\section{REFERENCES}

1. Consensus Development Statement. Who are candidates for prevention and treatment for osteoporosis? Osteop Int 1997;7:1-6.

2. Reginster JY. Antifracture efficacy of currently available therapies for postmenopausal osteoporosis. Drugs 2011;71(1):65-78.

3. Cosman F. Selective estrogen-receptor modulators. Clin Geriatr Med 2003;19(2):371-9.

4. Cetinkaya Demir B, Uyar Y, Ozbilgin K, Köse C. Effect of raloxifene and atorvastatin in atherosclerotic process in ovariectomized rats. J Obstet Gynaecol Res 2012 Jul 29. doi: 10.1111/j.1447-0756.2012.01969.x.
5. Riggs BL, Hartmann LC. Selective estrogen-receptor modulators - mechanisms of action and application to clinical practice. N Engl J Med 2003;348(7):618-29.

6. Ettinger B, Black DM, Mitlak BH. Reduction of vertebral fracture risk in postmanopausal women with osteoporosis treated with raloxifene. JAMA 1999;282(7):63745.

7. Helga Hansdottir. Raloxifene for older women: a review of the literature .Clin Interv Aging 2008;3(1);45-50.

8. Delmas Pierre D, Ensrud K, Adachi J. Efficacy of raloxifene on vertebral fracture risk reduction in postmanopausal women with osteoporosis: four-year results from a randomized clinical tria.j Clin Endocrinol Metab 2002;87(8):3609-17.

9. Holbrook TL, Barrett-Connor E, Wingard DL. Dietary calcium and risk of hip fracture. 14-year prospective population study. Lancet 1988;2(8619):1046-9.

10. Jensen GF.Osteoporosis of the slender smoker revisited by epidemiologic approach. Eur J Clin Invest 1986;16(3):239-42.

11. Brook JS, Balka EB, Zhang C. The smoking patterns of women in their forties: their relationship to later osteoporosis. Psychol Rep 2012;110(2):351-62.

12. Pinheiro MM, Reis Neto ET, Machado FS, Omura F, Yang JH, Szejnfeld J, Szejnfeld VL. Risk factors for osteoporotic fractures and low bone density in pre and postmenopausal women. Rev Saude Publica 2010;44(3):479-85.

13. McKinlay SM, Bifano NL, McKinlay JB. Smoking and age at manopause in women. Ann Intern Med 1985;103(3):350-56.

14. Dytfeld J, Ignaszak-Szczepaniak M, Gowin E. Influence of lean and fat mass on bone mineral density (BMD) in postmenopausal women with osteoporosis. Arch Gerontol Geriatr 2011;53(2):237-42.

15. El Hage R, Jacob C, Moussa E, Baddoura R. Relative importance of lean mass and fat mass on bone mineral density in a group of Lebanese postmenopausal women. J Clin Densitom 2011;14(3):326-31.

16. Krall EA, Dawson-Hugues B. Smoking and bone loss among postmenopausal women. J Bone Miner Res 1991;6(4):331-8.

17. Krall EA, Dawson-Hugues B. Smoking increases bone loss and decreases intestinal calcium absorption. J Bone Miner Res 1999;14(2):215-20.

18. Pereira RM, Carvalho JF, Paula AP, Zerbini C. Guidelines for the prevention and treatment of glucocorticoid-induced osteoporosis. Rev Bras Reumatol 2012;52(4):580-93.

19. Mizrak S, Yurekli B, Yilmaz C, Ercan G, Turan V. The effect of long-term nicotine exposure on bone mineral density and oxidative stress in female Swiss Albino rats. Arch Gynecol Obstet.2012 doi : 10.1007/s00404012-2535-8

20. Barbieri RL, Gochberg J, Ryan KJJ. Nicotine, cotinine, and anabasine inhibit aromatase in human trophoblast in vitro. Clin Invest 1986;77(6):1727-33. 
21. Silverman SL, Christiansen C, Genant HK. Efficacy of bazedoxifene in reducing new vertebral fracture risk in postmenopausal women with osteoporosis: results from a 3-year, randomized, placebo-, and active-controlled clinical trial. J Bone Miner Res 2008;23(12):1923-34.

22. Bjarnason $\mathrm{NH}$, Christiansen $\mathrm{C}$. The influence of thinness and smoking on bone loss and response to hor- mone replacement therapy in early postmenopausal women. J Clin Endocrinol Metab 2000;85(2):590-6.

23. Rapuri PB, Allagher JC, Balhorn KE. Smoking and bone metabolism in elderly women. Bone 2000; 27(3):429-36.

24. Chapurlat RD, Ewing SK, Bauer DC, Cummings SR. Influence of smoking on the antiosteoporotic efficacy of raloxifene. J Clin Endocrinol Metab 2001;86(9):4178-82. 